\title{
RAPID SURVEY PERILAKU MEROKOK PADA REMAJA DI KOTA TANGERANG SELATAN
}

\author{
Fenita Purnama \\ Sekolah Tinggi Ilmu Kesehatan Kharisma Persada \\ Tangerang Selatan, 15417 \\ E-mail: fenita.purnama@masda.ac.id
}

\begin{abstract}
ABSTRAK
Di Indonesia, lebih dari sepertiga atau 36,3 persen penduduk Indonesia saat ini menjadi perokok, bahkan 20 persen remaja usia 13-15 tahun adalah perokok. Saat ini, remaja laki-laki yang merokok kian meningkat. Data pada tahun 2016 memperlihatkan peningkatan jumlah perokok remaja laki-laki mencapai 58,8 persen. Kebiasaan merokok di Indonesia telah membunuh setidaknya 235 ribu jiwa setiap tahun. Tujuan penelitian ini untuk mengidentifikasi faktor-faktor yang berhubungan dengan perilaku merokok pada remaja di Kota Tangerang Selatan. Penelitian ini merupakan penelitian kuantitatif, menggunakan metode penelitian survei analitik dengan pendekatan cross sectional. Jumlah sampel yang didapat sebanyak 219 remaja. Sebab penelitian ini menggunakan metode Rapid Survey (Survei Cepat) dengan kriteria sampel sebanyak 210 sampai 300 responden. Hasil penelitian ini menunjukkan bahwa terdapat hubungan antara pengetahuan tentang rokok dengan perilaku merokok ( $p$ value $=0,046$ ), terdapat hubungan antara sikap tentang merokok dengan perilaku merokok ( $p$ value $=0,000)$, terdapat hubungan antara lingkungan sosial dengan perilaku merokok $(p$ value $=$ $0,000)$, dan terdapat hubungan antara peran petugas kesehatan dengan perilaku merokok ( $p$ value $=0,046)$.
\end{abstract}

Kata Kunci : : Rapid Survey, Perilaku Merokok, Remaja

\begin{abstract}
In Indonesia, more than a third or 36.3 percent of Indonesia's population are currently smokers, even 20 percent of adolescents aged 13-15 are smokers. Today, male adolescents who smoke are increasing. Data in 2016 showed an increase in the number of male smokers reaching 58.8 percent. Smoking habits in Indonesia have killed at least 235 thousand people every year. The purpose of this study was to identify factors related to smoking behavior in adolescents in South Tangerang City. This research is a quantitative research, using analytical survey research method with cross sectional approach. The number of samples obtained were 219 teenagers. Because this study uses the Rapid Survey method with a sample criteria of 210 to 300 respondents. The results of this study indicate that there is a relationship between knowledge about smoking and smoking behavior ( $p$ value $=0.046)$, there is a relationship between attitudes about smoking and smoking behavior ( $p$ value $=0,000)$, there is a relationship between social environment and smoking behavior ( $p$ value $=0,000)$, and there is a relationship between the role of health workers with smoking behavior ( $p$ value $=0.046)$.
\end{abstract}

Keywords $\quad$ : Rapid Survey, Smoking Behavior, teenagers 


\section{PENDAHULUAN}

\begin{abstract}
Bahaya mengkonsumsi tembakau dan merokok terhadap kesehatan merupakan sebuah kebenaran dan kenyataan yang harus diungkapkan secara sungguh-sungguh kepada seluruh lapisan masyarakat. Dengan demikian, masyarakat benar-benar memahami, menyadari, mau dan mampu menghentikan kebiasaan merokok dan menghindarkan diri dari bahaya akibat asap rokok. Selama ini, masyarakat telah terbuai dengan propaganda dan iklan rokok. Padahal itu tidak lebih dari sebuah kebohongan yang terus diulang-ulang, sehingga menjadi diyakini dan terinternalisasi dalam diri.
\end{abstract}

Data Kementerian Kesehatan menunjukkan peningkatan prevalensi perokok dari 27\% sejak tahun 1995, meningkat menjadi $36,3 \%$ pada tahun 2013. Artinya, jika 20 tahun yang lalu dari setiap 3 orang Indonesia 1 orang di antaranya adalah perokok, maka dewasa ini dari setiap 3 orang Indonesia 2 orang di antaranya adalah perokok.

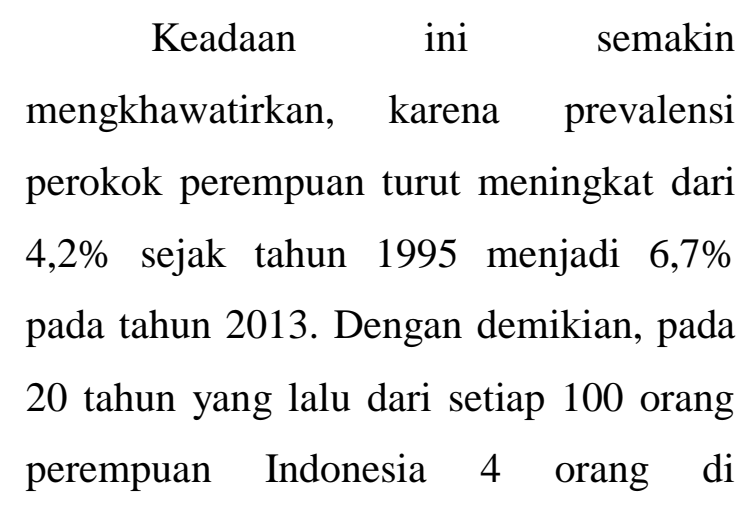

antaranya adalah perokok, maka dewasa ini dari setiap 100 orang perempuan Indonesia 7 orang di antaranya adalah perokok.

Data yang lebih memprihatinkan lagi adalah kebiasaan buruk merokok juga meningkat pada generasi muda. Data Kemenkes menunjukkan bahwa prevalensi remaja usia 16-19 tahun yang merokok meningkat 3 kali lipat dari 7,1\% di tahun 1995 menjadi 20,5\% pada tahun 2014. Dan yang lebih mengejutkan, lebih mengejutkan adalah usia mulai merokok semakin muda (dini). Perokok pemula usia 10-14 tahun meningkat lebih dari $100 \%$ dalam kurun waktu kurang dari 20 tahun, yaitu dari 8,9\% di tahun 1995 menjadi 18\% di tahun 2013.

Mengutip data hasil penelitian di RS Persahabatan dalam Alamsyah, 2007 memperlihatkan bahwa tingkat kecanduan atau adiksi pada anak SMA/Sederajat yang merokok cukup tinggi, yaitu $16,8 \%$. Artinya 1 orang dari setiap 5 orang remaja yang merokok, telah mengalami kecanduan. Penelitian ini juga memperlihatkan bahwa rata-rata anak yang dilahirkan oleh ibu hamil yang merokok memiliki berat badan yang lebih ringan $(<2500$ gram) dan lebih pendek (<45 cm) dibandingkan dengan ibu yang 
tidak merokok (>3000 gram) dan lebih panjang $(>50 \mathrm{~cm})$.

Di Indonesia, lebih dari sepertiga atau 36,3 persen penduduk Indonesia saat ini menjadi perokok, bahkan 20 persen remaja usia 13-15 tahun adalah perokok. Saat ini, remaja laki-laki yang merokok kian meningkat. Data pada tahun 2016 memperlihatkan peningkatan jumlah perokok remaja laki-laki mencapai 58,8 persen. Kebiasaan merokok di Indonesia

\section{METODE}

Jenis penelitian ini adalah deskriptif korelasi yaitu penelitian yang bertujuan untuk mengungkapkan hubungan korelasi antara korelatif, antara variabel independen dan variabel dependen. Pendekatan yang digunakan adalah pendekatan cross sectional yaitu suatu penelitian untuk mempelajari dinamika korelasi antara faktor dan resiko dengan efek cara pendekatan, observasi atau pengumpulan data sekaligus pada satu saat itu juga.

Populasi penelitian ini adalah seluruh siswa/i STM Sasmita Jaya Pamulang dan SMAN 6 Tangerang Selatan. Sampel yang digunakan pada penilitian ini adalah siswa/i STM Sasmita Jaya Pamulang dan SMAN 6 Tangerang telah membunuh setidaknya 235 ribu jiwa setiap tahun.

Badan Kesehatan Dunia (WHO) telah menempatkan Indonesia sebagai pasar rokok tertinggi ketiga dunia setelah Cina dan India. Prevalensi perokok lakilaki dewasa, saat ini bahkan paling tinggi di dunia. Akibatnya, Jaminan Kesehatan Nasional harus menanggung beban dari penyakit tidak menular (PTM) ini paling tinggi.

Selatan sebanyak 219 responden. Sebab penelitian ini menggunakan metode Rapid Survey (Survei Cepat) dengan kriteria sampel sebanyak 210 sampai 300 responden.

Rapid Survey (survei cepat) merupakan salah satu metode survei yang dimaksudkan untuk memperoleh informasi tentang suatu masalah dalam jangka waktu yang relatif pendek, dengan biaya yang terjangkau dan hasil yang optimal (Iswandi, 2009).

Hasil penelitian ini diolah dengan menggunakan epi info 7, sebuah program atau aplikasi pengolah data yang dicanangkan oleh WHO (World Health Organization). 


\section{HASIL}

\section{Hasil Analisis Univariat}

\section{a. Pengetahuan tentang rokok}

Berdasarkan hasil Tangerang Selatan, dapat dilihat penelitian, didapatkan kategori pada tabel 1 dibawah ini:

pengetahuan tentang rokok di Kota

Tabel 1. Distribusi Frekuensi Pengetahuan tentang Rokok pada Remaja di Kota Tangerang Selatan

\begin{tabular}{|c|c|c|}
\hline $\begin{array}{c}\begin{array}{c}\text { Pengetahuan tentang } \\
\text { rokok }\end{array} \\
\end{array}$ & Jumlah & Persentase $(\%)$ \\
\hline Baik & 199 & 90,87 \\
\hline Kurang Baik & 20 & 9,13 \\
\hline Total & 219 & 100,0 \\
\hline
\end{tabular}

Berdasarkan tabel 1, dapat diketahui bahwa 199 responden $(90,87 \%)$ dari 219 responden memiliki pengetahuan yang baik tentang rokok.

\section{b. Sikap tentang Merokok}

Berdasarkan hasil penelitian, didapatkan kategori sikap tentang merokok pada remaja di Kota Tangerang Selatan, dapat dilihat pada tabel 2 sebagai berikut:

Tabel 2. Distribusi Frekuensi Sikap tentang Perilaku Merokok Pada Remaja di Kota Tangerang Selatan

\begin{tabular}{|c|c|c|}
\hline $\begin{array}{c}\text { Sikap tentang } \\
\text { Merokok }\end{array}$ & Jumlah & Persentase $(\%)$ \\
\hline Baik & 151 & 68,95 \\
\hline Kurang Baik & 68 & 31,05 \\
\hline Total & 219 & 100,0 \\
\hline
\end{tabular}

Berdasarkan hasil tabel 2, dapat diketahui bahwa 151 responden $(68,95 \%)$ dari 219 responden memiliki sikap yang baik. 


\section{c. Lingkungan Sosial}

Berdasarkan hasil Tangerang Selatan, dapat dilihat penelitian, didapatkan kategori pada tabel 3 berikut ini:

lingkungan sosial remaja di Kota

Tabel 3. Distribusi Frekuensi Lingkungan Sosial Remaja di Kota Tangerang Selatan

\begin{tabular}{|c|c|c|}
\hline $\begin{array}{c}\text { Lingkungan Sosial } \\
\text { Remaja }\end{array}$ & Jumlah & Persentase (\%) \\
\hline Baik & 102 & 46,58 \\
\hline Kurang Baik & 117 & 53,42 \\
\hline Total & 219 & 100,0 \\
\hline
\end{tabular}

Berdasarkan tabel 3, dapat diketahui bahwa 102 responden $(46,58 \%)$ dari 219 responden memiliki lingkungan sosial yang baik.

\section{d. Peran Petugas Kesehatan}

Berdasarkan hasil Tangerang Selatan, dapat dilihat penelitian, didapatkan kategori pada tabel 4 berikut ini:

Peran Petugas Kesehatan di Kota

Tabel 4. Distribusi Frekuensi Peran Petugas Kesehatan di Kota Tangerang Selatan

\begin{tabular}{|c|c|c|}
\hline $\begin{array}{c}\text { Peran Petugas } \\
\text { Kesehatan }\end{array}$ & Jumlah & Persentase (\%) \\
\hline Baik & 161 & 73,52 \\
\hline Kurang Baik & 58 & 26,48 \\
\hline Total & 219 & 100,0 \\
\hline
\end{tabular}

Berdasarkan tabel 3, dapat diketahui bahwa 102 responden $(46,58 \%)$ dari 219 responden memiliki lingkungan sosial yang baik. 


\section{e. Perilaku Merokok}

Berdasarkan hasil Tangerang Selatan, dapat dilihat penelitian, didapatkan kategori pada tabel 5 dibawah ini:

perilaku merokok di Kota

Tabel 5. Distribusi Frekuensi Perilaku Merokok pada Remaja di Kota Tangerang Selatan

\begin{tabular}{|c|c|c|}
\hline Perilaku Merokok & Jumlah & Persentase (\%) \\
\hline Tidak & 163 & 74,4 \\
\hline Ya & 56 & 25,6 \\
\hline Total & 219 & 100,0 \\
\hline
\end{tabular}

Berdasarkan tabel 5, dapat diketahui bahwa 163 responden (74,4\%) dari 219 responden memiliki perilaku tidak merokok.

\section{Hasil Analisis Bivariat}

\section{a. Hubungan Pengetahuan}

\section{tentang Rokok dengan Perilaku}

\section{Merokok Pada Remaja}

Berdasarkan uji statistik,

didapatkan hasil pada tabel

sebagai berikut :

Tabel 6. Hubungan Pengetahuan tentang Rokok dengan Perilaku Merokok Pada Remaja

\begin{tabular}{|c|c|c|c|c|c|c|c|}
\hline \multirow{3}{*}{$\begin{array}{c}\text { Pengetahuan tentang } \\
\text { rokok }\end{array}$} & \multicolumn{4}{|c|}{ Perilaku Merokok } & \multirow{2}{*}{\multicolumn{2}{|c|}{ Total }} & \multirow{3}{*}{$P$ value } \\
\hline & \multicolumn{2}{|c|}{ Tidak } & \multicolumn{2}{|c|}{ Ya } & & & \\
\hline & $\mathbf{N}$ & $\%$ & $\mathbf{N}$ & $\%$ & $\mathbf{N}$ & $\%$ & \\
\hline Baik & 7 & 35,0 & 13 & 65,0 & 20 & 7 & \\
\hline Kurang Baik & 156 & 78,4 & 43 & 21,6 & 199 & 156 & 0,046 \\
\hline
\end{tabular}

Berdasarkan hasil dari

Hasil bivariat menunjukkan

tabel 6, maka dapat diketahui bahwa responden yang memiliki pengetahuan tentang rokok yang kurang baik lebih banyak yang merokok sebesar 13 responden (65\%) dibanding dengan yang tidak merokok sebesar 7 responden (35\%). bahwa terdapat hubungan antara tingkat pengetahuan tentang rokok dengan perilaku merokok pada remaja di Kota Tangerang Selatan, dengan $p$ value $=0,046$ ( $p$ value $<0,05)$. 


\section{b. Hubungan Sikap tentang}

\section{Merokok dengan Perilaku}

Merokok Pada Remaja

Berdasarkan uji statistik,

didapatkan hasil pada tabel

sebagai berikut :

Tabel 7. Hubungan Sikap tentang Merokok dengan Perilaku Merokok Pada Remaja

\begin{tabular}{|c|c|c|c|c|c|c|c|}
\hline \multirow{3}{*}{$\begin{array}{c}\text { Sikap tentang } \\
\text { Merokok }\end{array}$} & \multicolumn{4}{|c|}{ Perilaku Merokok } & \multirow{2}{*}{\multicolumn{2}{|c|}{ Total }} & \multirow{3}{*}{$P$ value } \\
\hline & \multicolumn{2}{|c|}{ Tidak } & \multicolumn{2}{|c|}{ Ya } & & & \\
\hline & $\mathbf{N}$ & $\%$ & $\mathbf{N}$ & $\%$ & $\mathbf{N}$ & $\%$ & \\
\hline Baik & 135 & 89,4 & 16 & 10,6 & 151 & 100 & \\
\hline Kurang Baik & 28 & 41,2 & 40 & 58,8 & 68 & 100 & 0,000 \\
\hline
\end{tabular}

Berdasarkan hasil dari

tabel 7 diatas maka dapat

diketahui bahwa responden yang

memiliki sikap tentang merokok yang kurang baik lebih banyak

yang merokok sebesar 40

responden $(58,8 \%)$ dibanding dengan yang tidak merokok sebesar 28 responden $(41,2 \%)$.

Hasil bivariat menunjukkan bahwa terdapat hubungan antara sikap tentang merokok dengan perilaku merokok pada remaja di Kota Tangerang Selatan, dengan $p$ value $=0,000$ ( $p$ value $<0,05)$.

\section{c. Hubungan Lingkungan Sosial}

dengan Perilaku Merokok Pada

\section{Remaja}

Berdasarkan uji statistik,

didapatkan hasil pada tabel

sebagai berikut :

Tabel 8. Hubungan Lingkungan Sosial dengan Perilaku Merokok Pada Remaja

\begin{tabular}{|c|c|c|c|c|c|c|c|}
\hline \multirow{3}{*}{ Lingkungan Sosial } & \multicolumn{4}{|c|}{ Perilaku Merokok } & \multirow{2}{*}{\multicolumn{2}{|c|}{ Total }} & \multirow{3}{*}{$P$ value } \\
\hline & \multicolumn{2}{|c|}{ Tidak } & \multicolumn{2}{|c|}{ Ya } & & & \\
\hline & $\mathbf{N}$ & $\%$ & $\mathbf{N}$ & $\%$ & $\mathbf{N}$ & $\%$ & \\
\hline Baik & 90 & 88,2 & 12 & 11,8 & 102 & 100 & \\
\hline Kurang Baik & 73 & 62,4 & 44 & 37,6 & 117 & 100 & 0,000 \\
\hline
\end{tabular}


Berdasarkan hasil dari

tabel 8, maka dapat diketahui

bahwa responden yang memiliki

lingkungan sosial yang kurang

baik lebih banyak yang tidak

merokok sebesar 73 responden

$(62,4 \%)$ dibanding dengan yang merokok sebesar 44 responden $(37,6 \%)$.

Hasil bivariat menunjukkan bahwa terdapat hubungan antara lingkungan sosial dengan perilaku merokok pada remaja di Kota Tangerang Selatan, dengan $p$ value $=0,000$ ( $p$ value $<0,05)$.

\section{d. Hubungan Peran Petugas}

\section{Kesehatan dengan Perilaku}

Merokok Pada Remaja

Berdasarkan uji statistik, didapatkan hasil pada tabel sebagai berikut :

Tabel 9. Hubungan Peran Petugas Kesehatan dengan Perilaku Merokok Pada Remaja

\begin{tabular}{|c|c|c|c|c|c|c|c|}
\hline \multirow{3}{*}{$\begin{array}{l}\text { Peran Petugas } \\
\text { Kesehatan }\end{array}$} & \multicolumn{4}{|c|}{ Perilaku Merokok } & \multirow{2}{*}{\multicolumn{2}{|c|}{ Total }} & \multirow{3}{*}{ P value } \\
\hline & \multicolumn{2}{|c|}{ Tidak } & \multicolumn{2}{|c|}{ Ya } & & & \\
\hline & $\mathbf{N}$ & $\%$ & $\mathbf{N}$ & $\%$ & $\mathbf{N}$ & $\%$ & \\
\hline Baik & 126 & 78,3 & 35 & 21,7 & 161 & 100 & 004 \\
\hline Kurang Baik & 37 & 63,8 & 21 & 36,2 & 58 & 100 & 0,046 \\
\hline
\end{tabular}

Berdasarkan hasil dari

tabel 9, maka dapat diketahui

bahwa responden yang

mendapatkan pelayanan dari

petugas kesehatan yang kurang

baik lebih banyak yang tidak

merokok sebesar 37 responden

$(63,8 \%)$ dibanding dengan. merokok sebesar 21 responden $(36,2 \%)$.

Hasil bivariat menunjukkan bahwa terdapat hubungan antara remaja mendapatkan pelayanan dari petugas kesehatan dengan perilaku merokok pada remaja di Kota Tangerang Selatan, dengan $p$ value $=0,046$ ( $p$ value <0,05). 


\section{DISKUSI}

\section{Hubungan Pengetahuan tentang Rokok}

\section{dengan Perilaku Merokok Pada Remaja}

Pengetahuan merupakan hasil tahu dan ini terjadi setelah orang melakukan penginderaan terhadap suatu obyek tertentu. Pengetahuan atau kognitif merupakan domain yang sangat penting untuk terbentuknya tindakan seseorang (Notoadmodjo, 2003). Lawrence Green sebagaimana dikutip Notoadmojo, 2003 juga mengatakan bahwa salah satu faktor yang menentukan perilaku seseorang yaitu faktor predisposisi termasuk diantaranya pengetahuan. Sementara itu, WHO dalam Notoadmojo (2003) menganalisis bahwa pengetahuan merupakan salah satu alasan pokok yang menyebabkan seseorang berperilaku.

Berdasarkan hasil penelitian pada tabel 6, maka dapat diketahui bahwa responden yang memiliki pengetahuan yang kurang baik yang merupakan perokok sebesar 13 responden (65\%) dibanding dengan yang tidak merokok sebesar 7 responden (35\%). Hasil bivariat menunjukkan bahwa terdapat hubungan antara pengetahuan tentang rokok dengan perilaku merokok pada remaja di Kota Tangerang Selatan, dengan $p$ value = $0,046$ ( $p$ value $<0,05)$.

Penelitian ini sejalan dengan hasil penelitian yang dilakukan oleh
Sulistyawan (2012) menyatakan bahwa adanya hubungan antara pengetahuan dengan perilaku merokok remaja di Kota Tangerang Selatan. Pengetahuan berpengaruh terhadapa perilaku merokok pada remaja. Beberapa penelitian sebelumnya, seperti penelitian Aji (2003) juga menyatakan bahwa adanya hubungan antara pengetahuan dengan perilaku merokok remaja, dalam hal ini sasaran penelitian yang dimaksud adalah siswa SMPN 3 Kota Tangerang Selatan.

Sesuai dengan hasil penelitian, dapat dilihat bahwa remaja berpengetahuan tidak baik lebih banyak yang merokok dibanding yang tidak merokok, kecenderungan ini dapat disebabkan oleh beberapa faktor seperti kurangnya pengetahuan remaja tentang bahaya dari perilaku merokok, sesuai dengan teori (Notoadmodjo, 2003) yang menjelaskan bahwa pengetahuan atau kognitif merupakan domain yang sangat penting untuk terbentuknya tindakan seseorang. Jika seseorang memiliki pengetahuan yang kurang baik, maka tindakan yang ia lakukan juga lebih beresiko terhadapat perilaku yang menyimpang. 


\section{Hubungan Sikap tentang Merokok dengan Perilaku Merokok Pada}

Sikap merupakan reaksi atau respons seseorang yang masih tertutup terhadap suatu stimulus atau objek. Dari batasan-batasan yang ada bahwa manefistasi sikap itu ditafsirkan terlebih dahulu dari perilaku yang tertutup.

Berdasarkan hasil dari tabel 7 diatas maka dapat diketahui bahwa responden yang memiliki sikap tentang merokok yang kurang baik lebih banyak yang merokok sebesar 40 responden $(58,8 \%)$ dibanding dengan yang tidak merokok sebesar 28 responden $(41,2 \%)$.

\section{Hubungan Lingkungan Sosial dengan}

\section{Perilaku Merokok Pada Remaja}

Menurut Komalasari \& Helmi (2000), faktor-faktor yang menyebabkan perilaku merokok adalah faktor lingkungan sosial. Selain itu, faktor psikologis dimana merokok dapat menjadi sebuah cara bagi individu untuk santai dan kesenangan, tekanan-tekanan teman sebaya, penampilan diri, sifat ingin tahu, stress, kebosanan dan ingin kelihatan gagah merupakan hal-hal yang dapat mengkontribusi mulainya merokok.

Berdasarkan hasil penelitian pada tabel 8, maka dapat diketahui bahwa responden yang memiliki lingkungan sosial yang kurang baik lebih banyak yang tidak merokok sebesar 73 responden $(62,4 \%)$ dibanding dengan yang merokok

\section{Remaja}

Hasil bivariat menunjukkan bahwa terdapat hubungan antara sikap tentang merokok dengan perilaku merokok pada remaja di Kota Tangerang Selatan, dengan $p$ value $=0,000(p$ value <0,05 $)$. sikap merupakan predisposisi (penentu) yang memunculkan adanya perilaku yang sesuai dengan sikapnya. Sikap tumbuh di awali dari pengetahuan yang disersepsikan sebagai suatu hal yang baik maupun tidak baik, kemudian di internalisasikan kedalam dirinya.

sebesar 44 responden (37,6\%). Hasil bivariat menunjukkan bahwa terdapat hubungan antara lingkungan sosial dengan perilaku merokok pada remaja di Kota Tangerang Selatan, dengan $p$ value = 0,000 ( $p$ value <0,05).

Penelitian ini sejalan dengan hasil penelitian yang dilakukan oleh Sulistyawan (2012) yang menyatakan bahwa ada hubungan antara lingkungan sosial seperti (pengaruh orang tua, pengaruh teman sebaya dan pengaruh iklan) dengan perilaku merokok pada remaja.

Hasil penelitian ini menunjukkan bahwa lebih banyaknya responden yang tidak merokok hidup di lingkungan sosial 
yang kurang baik. Hal ini bisa disebabkan oleh beberapa faktor diantaranya pengetahuan tentang bahaya dari perilaku merokok ataupun kesadaran dari responden tersepon tentang perilaku penyimpang dalam merokok. Jadi dapat ditarik kesimpulan bahwa seseorang yang hidup di lingkungan social yang kurang baik belum tentu memiliki perilaku yang tidak baik, seperti merokok. Hal ini tergantung dari kesadaran sikap masingmasing individu.

\section{Hubungan Peran Petugas Kesehatan dengan Perilaku Merokok}

Dalam UU Nomor 23 Tahun 1992 tentang Kesehatan yang dimaksud tenaga kesehatan adalah setiap orang yang mengabdikan diri dalam bidang kesehatan, memiliki pengetahuan dan atau keterampilan melalui pendidikan di bidang kesehatan yang memerlukan kewenangan dalam menjalankan pelayanan kesehatan.

Profesi kesehatan, terutama pada dokter dan paramedis mempunyai peran sangat dalam promosi berenti merokok dan menjadi contoh dalam masyarakat. Kebiasaan merokok pada petugas kesehatan harus segera dihentikan. Selanjutnya petugas kesehatan diyakini mempunyai peran mencapai $10 \%$ dalam mendorong pasien untuk berenti merokok. Caranya dengan memberi intruksi dengan tegas kepada pasien dengan berenti merokok.

Berdasarkan hasil penelitian pada tabel 9, maka dapat diketahui bahwa responden yang mendapatkan pelayanan dari petugas kesehatan yang kurang baik lebih banyak yang tidak merokok sebesar 37 responden $(63,8 \%)$ dibanding dengan. merokok sebesar 21 responden $(36,2 \%)$. Hasil bivariat menunjukkan bahwa terdapat hubungan antara remaja mendapatkan pelayanan dari petugas kesehatan dengan perilaku merokok pada remaja di Kota Tangerang Selatan, dengan $p$ value $=0,046$ ( $p$ value $<0,05)$.

Peran petugas kesehatan sangatlah berpengaruh terhadap perilaku kesehatan atau pandangan kesehatan dari seorang individu. Dari penelitian yang kami lakukan menunjukkan bahwa 63,8\% dari 219 yang bukan perokok mendapatkan pelayanan kesehatan dari petugas kesehatan yang kurang baik, seperti (penyuluhan tentang merokok pada remaja, sosialisasi melalui iklan tentang bahaya merokok).

Petugas kesehatan mempengaruhi derajat kesehatan seseorang, namun bukan berarti seseorang yang mendapatkan pelayanan kesehatan yang kurang baik memiliki perilaku yang menyimpang seperti merokok hal ini tergantung dari sikap individu seseorang atau tingkat 
kesadaran seseorang, sesuai dengan penelitian yang kami lakukan bahwa walaupun pelayanan yang didapatkan responden kurang baik namun responden yang merokok lebih sedikit disbanding yang tidak merokok.

\section{SIMPULAN}

Hasil penelitian ini menunjukkan bahwa terdapat hubungan antara pengetahuan tentang rokok dengan perilaku merokok ( $p$ value $=0,046)$, terdapat hubungan antara sikap tentang merokok dengan perilaku merokok ( $p$

\section{DAFTAR PUSTAKA}

Aditama, Tjandra yoga. 1992. Rokok dan kesehatan. Jakarta: UI press.

Ahmad, R.R. 2010. Merokok Haram. Jakarta: PT. Gramedia.

Aji, Kandi Senti. 2003. Gambaran perilaku merokok dan faktor yang mempengaruhinya pada pelajar SLTPN di Depok tahun 2002 : Universitas Indonesia

Alamsyah, Rika Mayasari. 2007. Faktorfaktor yang mempengaruhi kebiasaan merokok dan hubungannya dengan status penyakit periodontal remaja di kota Medan tahun 2007 : Universitas Sumatera Utara

Arikuntoro, Suharsimi. 2002. Metodologi Penelitian. Jakarta: Rineka Cipta.

Iswandi. 2009. Aplikasi Rapid Survey. Available at URL: http://djoko.nugroho.undip.ac.id/fil
Saat ini kurangnya kepercayaan seseorang terhadap promosi kesehatan dikarnakan perilaku petugas kesehatan yang tidak mencerminkan kebiasaan dalam menunjang derajat kesehatan, hal ini dibuktikan masih banyaknya petugas kesehatan yang berperilaku merokok.

value $=0,000)$, terdapat hubungan antara lingkungan sosial dengan perilaku merokok $(p$ value $=0,000)$, dan terdapat hubungan antara peran petugas kesehatan dengan perilaku merokok ( $p$ value $=$ 0,046).

es/2009/II/lectureI.pdf. Diakses pada tanggal 05 Oktober 2017.

Komasari, D. \& Helmi, AF. 2000. Faktor - Faktor Penyebab Perilaku Merokok Pada Remaja. Jurnal Psikologi Universitas Gajah Mada, 2. Yogyakarta: Universitas Gajah Mada Press.

Notoatmodjo, Soekidjo. 2003. Pendidikan dan Perilaku Kesehatan. Jakarta: Rineka Cipta.

Notoatmodjo, Soekidjo. 2012. Metodologi Penelitian Kesehatan. Jakarta: Rineka Cipta.

Octarina, M dan Rachmawati M.A. Hubungan Antara Konformitas dengan Perilaku Merokok. Yogyakarta: Program Studi Psikologi Fakultas Psikologi dan Ilmu Sosial Budaya Universitas Indonesia. 
Sinaga, Sarman. 2016. Hubungan Antara Pengetahuan Tentang Rokok, Teman Sebaya, Orang Tua yang Merokok, dan Iklan Rokok Terhadap Perilaku Merokok pada Mahasiswa Akademi Kesehatan X di Rangkasbitung. Banten: AKPER Yatna Yuana Lebak.

Sulistyawan, Ade. 2012. Faktor-Faktor yang Berhubungan dengan Perilaku Merokok Siswa SMPN 3 Kota Tangerang Selatan tahun 2012. Jakarta: Program Studi Ilmu Keperawatan Fakultas Kedokteran dan Ilmu Kesehatan Universitas Islam Negeri Syarif Hidayatullah.

Widiyanti, Efri. 2007. Remaja dan Permasalahannya: Bahaya
Merokok, Penyimpangan Seks pada Remaja dan Bahaya Penyalahgunaan Minuman Keras/Narkoba. Makalah dalam Penyuluhan Mengenai Remaja dan Permasalahannya di Tsanawiyah Banuraja dan Tsanawiyah Al Ihsan Batujajar Kabupaten Bandung.

Wulandari, Hesti. 2011. Hubungan Usia, Pola Asuh Orang Tua dan Lingkungan Sosial dengan Kejadian Merokok pada Remaja di dusun Widoro Bangunharjo Sewon Bantul Yogyakarta. Yogyakarta: Program Studi Ilmu Kesehatan Sekolah Tinggi Ilmu Kesahatan'Aisyiyah. 